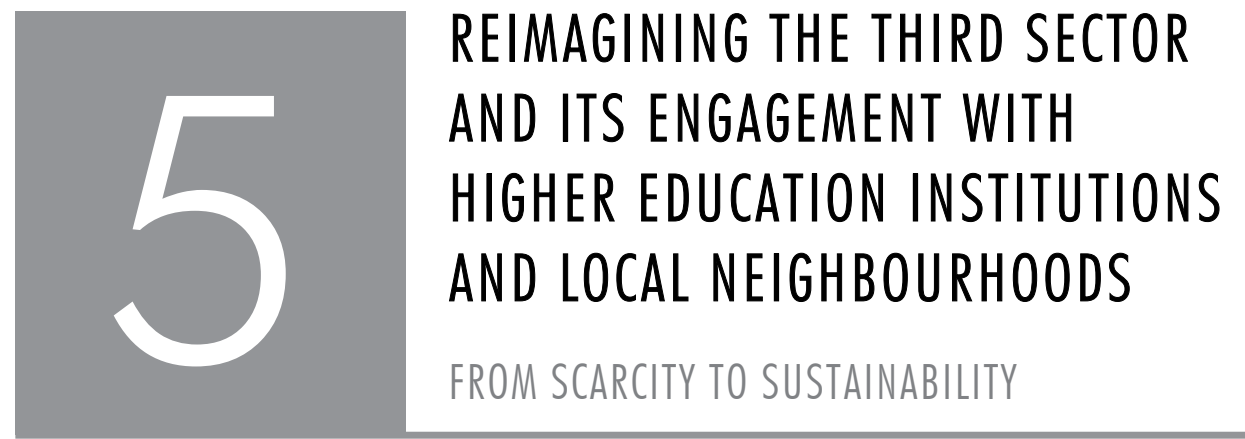

\title{
Stephan de Beer
}

\section{ABSTRACT}

This chapter presents a conceptual narrative, arguing that the third sector, if reimagined, can contribute significantly to enabling reciprocal knowledge between itself, local neighbourhoods and higher education institutions. Such a reimagination of itself drawing from a spirituality of abundance, exploring innovation and enterprise, and fostering practices of sustainability - would enable optimal partnerships with local neighbourhoods and higher education institutions hopefully resulting in more sustainable transformations. The last part of the chapter envisages local neighbourhoods in the inner city of Tshwane as possible sites of engagement, in which the proposals of this chapter can be tested. 


\section{INTRODUCTION}

Local neighbourhoods require strong socio-economic, physical and natural infrastructure to be viable, sustainable and resilient. The third sector - communitybased, faith-based and non-profit organisations (NPOs), local citizens or citizens' groups - and higher education institutions ( $\mathrm{HEls}$ ), in collaboration with local neighbourhoods, could help facilitate, ensure and sustain the institutional infrastructure required for such neighbourhoods. In this chapter I explore the tension between the undervalued significance of the third sector in bringing about transformational change, on the one hand, and the vulnerability of the third sector, as well as its own undervaluation of itself, on the other.

Third sector organisations are increasingly significant not only in local development engagements but also nationally and transnationally. However, the reality is that the same third sector seeking to mediate the well-being of their own local neighbourhoods are at times as vulnerable and unsustainable as the people and neighbourhoods they seek to accompany towards well-being. How do we therefore ensure a vibrant and sustainable third sector to continue as agents, facilitators and brokers of healthy local communities (neighbourhoods made up of people, places and power)?

At the same time the relationships between third sector organisations, HEls and local neighbourhoods are often fragmented, engagements sporadic and unstrategic, and knowledge either disabling rather than enabling, or insufficiently enabled for different publics in order to have optimal transforming benefits.

In this chapter I would like to argue that a reimagined third sector can make a significant contribution to enabling reciprocal knowledge between itself, HEls and local neighbourhoods, which, as a result, could help foster new and different ways of collaboration, greater sustainability of the third sector and the possibility of healthier, more sustainable, and indeed resilient local neighbourhoods.

The first part of the chapter focuses on reimagining a third sector that has a strong and self-critical consciousness of its own agency and knowledges, cultivates a spirituality of abundance, embraces shifts towards greater innovation in its enterprise, and fosters paradigms of sustainability. The second part of the chapter will reimagine the engagement between the third sector, HEls and local neighbourhoods, with specific reference to narratives from the inner city of Tshwane.' Such a reimagined third sector would consider the possibility of enabling reciprocal knowledge with the potential to facilitate shifts in and between these different sectors and to contribute more specifically to the well-being and resilience of local neighbourhoods.

1 City of Tshwane Metropolitan Municipality, which includes Pretoria. 


\section{REIMAGINING THE THIRD SECTOR}

In proposing a reimagined third sector, four key elements - consciousness and agency, abundance, innovation and sustainability - are explored.

\subsection{Fostering third sector consciousness: From charity and scarcity to agency}

Most community organisations in South Africa are largely dependent on outside resources, other than on self-generated resources, for their continued existence. Although most community organisations will at some point claim empowerment as part of their mission - to help dependent individuals, families or communities, to break the cycles of poverty and dependence, and to find a greater sense of self-reliance very few community organisations can actually demonstrate such self-reliance.

What is the dominant consciousness at work in the lives, minds and practices of community organisations? It is a matter of self-definition - the language we use for ourselves, the concepts we hold of ourselves, the way we carry ourselves, the manner in which we relate to those with more or less power than our own? Is the dependency and lack of sustainability of many community organisations not often the result of a dominant consciousness that is dictated by a scarcity- (or crumb-) mentality (Covey 1991; Walker 1991), a lack of robust and appreciative self-definition, and entrenched paradigms of dependency and service?

A few of these self-limiting notions are scrutinised further.

\subsubsection{The danger of charity}

Traditionally, 'charities' referred to organisations providing services to help the poor. In Biblical references 'charity' not only refers to particular practices, but it is also seen as a virtue - meaning unlimited love and kindness. In the Hebrew Bible charity is a characteristic of a righteous person: a righteous person practices charity, which is to give to the poor.

And yet, in our culture, the practice and virtue of charity have been distorted into something different to unlimited love and kindness. Charity has often become a practice of resource-rich people (power) providing handouts to resource-poor people (powerless) in ways that do not establish relationships of mutuality or equality. Charity too often leads to dependency and a perpetuation of inequality: that which is done to silence consciences, without a more fundamental restructuring of the way in which resources are gathered, accumulated or distributed. Too often charity is simply devised to keep exclusive tables intact, based on a premise of scarcity, and therefore 
true sharing of abundant resources is prevented and nothing changes fundamentally (Covey 1991).

Too often third sector organisations themselves have developed beggar mentalities, doing everything required of them by donors (private or public), even if it is to deviate from their primary vocation, as long as they can retain their income.

If originally the term 'charity' was used to describe unlimited love and kindness expressed by righteous people in solidarity with those who were vulnerable, to reorganise the tables of humanity, then I want to suggest that the word has been co-opted by other agendas and reduced to alms-giving to keep the poor at bay. And therefore the third sector needs new language to define it, as well as the actions it undertakes, anew. If charity simply means to keep the current systems of the city and the world intact, and if those of us working in third sector organisations have become agents to make resource-rich people be less concerned about the disparities in our world, then we have lost the plot and our vocation with it. The vocation of third sector organisations is to facilitate greater degrees of human dignity, socio-economic equality, political agency, environmental justice, and working for wholeness of society in every respect.

Charity is the much more radical task of restructuring the way things are, instead of merely passing crumbs from rich to poor. If breaking the cycles of poverty, if rearranging the tables so that all can be seated and accessing resources of sustainable livelihoods, if subverting the tables of the rich, is what we do and then that is called charity, then charity is just. But if what we do is the kind of charity that consists of handouts keeping the disparities, dependencies, scarcities and distances in place, while some can never access sources of power, such charity has no justice to it.

\subsubsection{The problem of non-profits}

In the South African context most community organisations are registered as NPOs in terms of the Nonprofit Organisations Act 71 of 1997 (RSA DoSD). Such organisations include community-based organisations, faith-based organisations, civic associations, sporting clubs, and a variety of other groups and institutions registered to operate without a profit motive. As with the notion of charity, although perhaps less pronounced, there are problems with the language of non-profits.

Firstly, most people associated with NPOs seem to think that they are not allowed to make profit at all. Some are even outright scared or sceptical about the notion of profit. And yet, that is of course not the case. NPOs are not primarily designed to make profit but are allowed to generate profits as long as such profits are ploughed 
back into the core objectives of the company as spelled out in its institution, and as long as the profit is not more than a specified percentage of the organisation's total income. In a case where non-profits generate substantial profits, a separate special purpose vehicle might have to be created that will be taxable, but the profits will be reinvested for non-profit purposes. The point is simply this: NPOs are allowed to show profits and do not have to shy away from this possibility.

The deeper problem with the language of non-profits is the way in which the whole sector is defined in terms of what it is not. It is not a distinguishable sector such as the private sector or the public sector or the tertiary sector. It only speaks about what it is not, without actually describing what it actually is. Part of the legacy of Steve Biko (2002) and others was to help us see that one can never define someone in terms of who they are not. In the days of apartheid the language of 'whites' and 'non-whites', or even worse, 'Europeans' or 'non-Europeans', was common to describe different racial groups. Black people were defined in terms of who they were not. But who were they then? I could be accused of playing a semantic game. And yet, there is a depth of meaning and value in the language we use regarding ourselves. If we are only able to define ourselves in terms of who or what we are not, if we are not able to define ourselves clearly in terms of who we are, boldly and without apology, it might result in a lack of clear identity, which will bind us to the kind of captivity to crumbs that contemporary charity has brought about. We need to break those shackles if we, and those we want to be in solidarity with, are to be free.

\subsubsection{The significance of the third sector}

In response to this dilemma of language some consequently argue for other concepts and languages such as those of the community sector or voluntary sector. I would like to propose that we think of the third sector as it has become commonly known in places like France, Japan and the UK (HM Treasury 2007; Hull 2007). The International Society for Third-Sector Research (ISTR nd) is bringing together hundreds of scholars, researchers and practitioners, devoted to the study of civil society, non-profits and philanthropy, under the rubric of the third sector, now being internationally widely recognised. So whereas the term 'public sector' refers to government and 'private sector' to business, the 'third sector' refers to civil society organisations or, defined differently, the social economy.

Nation states are increasingly recognising the importance of the third sector in terms of how it contributes to the social infrastructure and well-being of society at large, and vulnerable populations in particular. If one were to take non-profits out of the equation in South Africa, many communities and vulnerable groups would be 
completely exposed - consider social infrastructure in communities, the distribution of anti-retroviral drugs, the care of orphans and vulnerable children, support for homeless people and victims of domestic violence, the delivery of social housing, and so forth.

The Leprosy Mission, which has been in existence since 1874, and in South Africa since 1949 (Moller 2014), and whose mission is to address the challenges of people living with leprosy, has been largely in-sourced by the Department of Health for managing leprosy work in South Africa as a whole because of their history, legacy, credibility and the sophistication with which they have done their work over many years. Although leprosy has been reduced to the point of a small incidence rate in South Africa, this is one example of a third sector organisation adding significant value to society at large and probably at a fraction of the cost if it was to be done by the public or private sector instead.

From an economic point of view, nation states have started to recognise the importance of this sector $-12 \%$ of the workforce in France is active in the third sector and in some Scandinavian countries it might be closer to $20 \%$. The housing solution of some countries lies completely with the third sector. The third sector contribution to the gross domestic product (GDP) of some countries is to the extent of $12-20 \%$. There is no way in which this could be discarded as insignificant (HM Treasury 2007; Hopkins 2010; Hull 2007).

Often the soul of a community is kept intact because of enduring third sector presence; when others disinvest, third sector organisations often take considerable risks to remain. The language of third sector organisations is often couched in terms such as 'compassion', 'justice', 'solidarity' and 'dignity', in a much more natural way than in the private or public sector. This is soul language that can help sustain communities, even, and especially, when infrastructure is scarce or under threat. The importance of this sector for stable and healthy societies should never (or no longer) be underestimated.

\subsubsection{Consciousness and agency}

Not only is the work done by the third sector about affirming a new consciousness of this sector, both within the sector itself and with those outside the sector as they perceive and partner with it, but it is also about a deeply personal journey for those actively involved in this sector. Embracing the belonging to this sector needs to go hand in hand with embracing the sector's own agency, an acknowledgement that 'it is up to us'. It might be 'up to us' to eradicate homelessness from the city streets, to arrest decay in certain neighbourhoods, to provide top-up services for school leavers 


\section{REIMAGINING THE THIRD SECTOR, HIGHER EDUCATION INSTITUTIONS AND LOCAL NEIGHBOURHOODS}

to ensure that they do not become the next generation of unemployed young people, and to foster a sense of manhood and womanhood that will help address gender violence and inequities.

In 2013 the theme of the annual Feast of the Clowns, hosted by the Tshwane Leadership Foundation, an inner city third sector organisation in Pretoria/Tshwane, was "It is up to us". The aim was to explore the responsibilities, ownership and agency that ordinary people, third sector organisations and HEls need to embrace, on their own but also in partnership, in response to some of the greatest societal challenges.

This notion of agency does not imply that third sector organisations should engage challenges exclusively, or that it is 'up to us' alone, but it does imply a very deliberate embracing of challenges by the third sector in the sense of taking ownership, of building partnerships, of acknowledging its distinctive vocation, strengths and capabilities, together with many others.

Embracing the sector's own agency could imply starting to address challenges with which public sector and private sector organisations are not willing to engage. Sometimes it would mean crafting good practices in ways that might eventually inform local and even national policies and strategies. It often requires long processes of education and conscientisation for certain issues to be articulated well, until they become priority areas for all sectors.

The consciousness and agency (De Gruchy 2003) spoken of here should not be based on a false sense of confidence. It should be nurtured slowly, emanating from a deep rootedness in communities, intuitive knowledge developed over time, hard work to build a knowledge and capacity base, years of engagement and experience, well-developed skills and competencies, proven track records, broken cycles of violence and poverty evidenced in communities, measured and well-articulated impact, and sustained, humble service. All of this work needs to be done until third sector organisations are distinguished by others as the leaders in their respective fields.

This chapter suggests that for third sector organisations to be much more intentional about fostering own consciousness and agency, it is crucial that they have a deep self-understanding, rooted in clear values, and clarity of vision, mission and self-definition. It is a consciousness deliberate about deconstructing societal narratives that are oppressive and exclusive, affirming and appreciating own agency and assets and - even more importantly - having a deep appreciation for the agency and assets of the people and communities with which it journeys. 


\subsection{Cultivating a spirituality of abundance}

It is vital for the third sector to develop a new self-consciousness through cultivating a spirituality of abundance. Such spirituality will help organisations overcome a scarcity mentality and result in them engaging boldly as equal partners with HEls and both the public and private sectors.

Walker (1991) contrasts a spirituality of abundance with a theology of crumbs, suggesting that too often development aid, third sector organisations, HEls and churches have a 'crumb mentality', waiting for crumbs to fall off rich people's tables (as in the Biblical story of Lazarus and the rich man), instead of using own agency and consciousness to create their own tables.

If the generic vocation of third sector organisations is to work for the common good of all people, which I suppose could be the case, obviously in partnership with many others, it can only sustain such a quest, if it is rooted in a firm conviction of the abundance of the global household. The Greek word oikos is the word for household and the root word for both economy and ecology. Ecology refers to the structure of the household, and economy to the way in which the household is managed, that is, how resources are distributed and shared, among other things.

A spirituality of abundance will not only affirm the abundance of the global household (ecology). It will also spend much time to foster practices and disciplines that will be concerned with both how to protect and sustain the structure of the household - for if we do not sustain it, it cannot sustain us - and with how resources are shared in this household.

Rooted in a spirituality of abundance, it then becomes possible for third sector organisations and their partners to believe in the possibility of sustainable communities and sustainable community organisations, to become bold in seeking innovative change that would be radically inclusive of the most vulnerable sectors of society, and to foster engagement with HEls as equal partners. All of this becomes possible if premised on a spirituality of abundance, drawn from a theology of creation or a paradigm of an interconnected and interdependent global household (Fox 2000; Covey 1991). It will affirm that the abundant resources of God (Brueggemann 1993) are enough for our sustenance, that of our communities, and that of future generations, if such resources are distributed in a just, inclusive and responsible manner. 


\subsection{Embracing (social) innovation and (social) entrepreneurship}

The significance of the third sector often lies with the (social) innovations that it facilitates to engage with societal challenges. A more deliberate self-consciousness will include an intentionality about innovation, creative ways of retrieving, capturing, articulating and sharing innovations that occur, to help change paradigms, processes, practices and programmes, not only at local level, but even nationally and globally. Of particular value in recent years was the work done by organisations such as Ashoka Innovators for the Public, the Schwab Foundation and the Skoll Foundation, not only to promote but also to reward and broadcast social innovation, assisting in scaling, replicating and multiplying good practices with the potential to transform systems, communities and people alike.

Closely linked to the concept of social innovation, although not necessarily to be equated with each other, is the concept of social entrepreneurship. Entrepreneurs are people who see a gap in the market, and they create an innovative response to address a certain gap in a way that is financially not only sustainable but also profitable. Social entrepreneurs create social enterprises. Social entrepreneurs are people who see a gap or challenge in society, and then create an innovative response to make a change in terms of that particular issue in ways that are financially sustainable, and sometimes also profitable (Bornstein 2007).

The difference between NPOs and social enterprises are often the deliberate intention of social enterprises to ensure profit that is social, financial and environmental. A critical challenge to be further interrogated is in how far social enterprises could be created that would be rigorous in seeking to connect and embody both social innovation in the best sense of the word and with a deep sense of social justice, restructure the way the resources of the world are shared. Third sector organisations would do well to nurture reflective practices that will facilitate the best of social innovations for this and generations to come, and to embrace and encourage social entrepreneurship as a way to arrest and overcome some of the greatest challenges of society.

\subsection{Fostering paradigms of sustainability}

Flowing from a spirituality of abundance, and conscious practices of social innovation, should be an insistence on fostering new paradigms of sustainability. Sustainability, in the context of this chapter, refers to the global and national household, the local household (community or neighbourhood), as well as the community and the third sector organisation living and participating in the global, national and local households (Cobb 1992). 
The Brundtland Commission (1987:16) of the United Nations defined sustainable development as "development that meets the needs of the present without compromising the ability of future generations to meet their own needs". Whether the global or local neighbourhood or household, or the local third sector organisation, the concept and challenge of sustainability remain the same: to ensure that there are enough resources today, equitably distributed, and that they are used responsibly in order for future generations to have adequate, sustainable and equitable resources. In this section I focus on sustainability in relation to local communities.

All community organisations are challenged and struggling with long-term sustainability. The questions that arise in this context are the following:

- How do we build local community organisations and civic infrastructure that last?

- How do we leave a legacy beyond the phase of the pioneer or the entrepreneur?

- How do our current actions outlive the current generation for future generations to benefit from them?

- How do we generate resources to sustain our actions?

Too often we think of sustainability only in terms of financial well-being. Some people focus on environmental concerns. In fostering paradigms of sustainability it is important to embrace a vision of sustainability that is intentional about fostering three overlapping and interconnected circles of sustainability in local community organisations and in local communities: the social circle (people), the economic circle (profit) and the environmental circle (planet) (Figure 5.1).

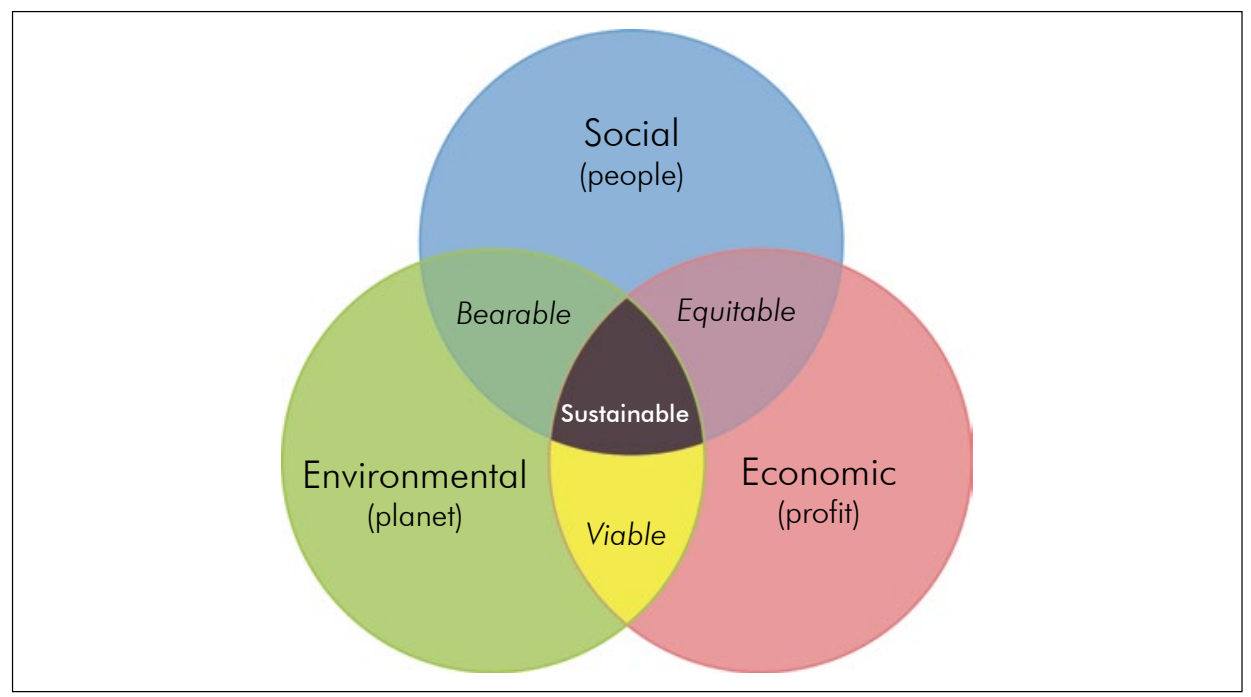

FIGURE 5.1 The three pillars of sustainability [Wikipedia 2006] 
Socially and organisationally our actions must ensure the highest degree of equity and equality. Environmentally our actions must be such that the structure of the household can be bearable and durable for generations to come. Economically our actions must ensure viability for future existence. It is in the overlapping work to ensure all of these, often in a delicate relationship with each other, that sustainability will be achieved.

\subsubsection{The social circle}

Sustainability is not just about environmental and financial resources. In third sector organisations sustainability starts with the right people, being aligned to shared values and visions, and being committed to developing disciplines and processes that will continuously root the organisation, its people and its programmes, in the shared values and vision. As Collins (2001) suggests in Good to great, so-called great organisations are organisations that have the right people: people owning and embodying the values and visions of the organisations in the right places and aligned to their own strengths.

Sometimes sustainability requires not numerical or vertical growth, but rather a consolidation of growth. Scaling (Hurst 2012) is often narrowly interpreted as implying increased numbers and expanded impact in more places. Sometimes that is the last option if an organisation wants to live into the future - then, at a given time, trimming to scale (or reducing numbers) is what would be required to sustain both organisation and impact, and perhaps facilitate growth in terms of quality and depth. It is also in this regard that strong partnerships with HEls can accelerate and deepen impact.

It is often at the level of organisational praxis that third sector organisations falter. Sustainability is not only about financial viability, environmental well-being, social equity, or the right values, visions and people - the deeper question is whether we have an organisational praxis that can sustain whatever we are about.

\subsubsection{The economic circle}

Sustainability is also about how we develop, manage, distribute and share economic resources - financial and material - in the global and local household.

Third sector organisations often find themselves in the space between resources and deficiencies, serving as catalysts or brokers for social and economic investments, usually in the hope that it would contribute to reducing the disparities between rich and poor. And yet, too often, this happens from a base of weakness and deficiency, from a scarcity mentality instead of from bold, conscious agency that is committed 
to rewriting local stories of communities and of the organisations accompanying communities. Third sector organisations need to develop their own capacity to participate more rigorously in local economic development processes that would not only sustain themselves, but thereby also contribute significantly to local economic sustainability. Why is it that the profits of McDonald's and all similar franchise stores in my neighbourhood leave the area after closing time? Third sector organisations or local communities should perhaps explore investment in local business ventures that will generate profit, to be reinvested into local communities towards greater sustainability (Lupton 1993).

In the South African context many organisations have experienced financial crisis in the past few years, and even some of the strongest and most reputable organisations have had to close their doors because they could not sustain themselves financially any longer. Often such crises are caused by a lack of innovation in their funding strategies, or a lack of broad-based strategies. Consequently such organisations rely almost entirely on one donor for their budget, and when donor policy changes and the donor withdraws they have no choice but to close their doors (Calland 2013; Stuart 2013). What is required is probably a reimagined self-understanding within third sector organisations, disentangling themselves from a complete dependency on external resources, and seeking to become more innovative and entrepreneurial in building sustainable organisational models.

On the one hand they could continue to create a broad-based funding plan including support from individuals, friends, churches, the private sector, corporate social investment, government subsidies, donor agencies, bequests, trusts and foundations. But they should also go beyond that in creating the capacity for enterprise development, that is, rendering services for fees, doing consulting work, entering into government contracts, and embarking on own enterprise development. In engaging with HEls, third sector organisations could create the possibility of offering their agency and wealth of knowledge as consultants or educators.

A reimagined third sector would include in any long-term sustainability strategy a strong and measurable impact assessment tool to ensure that impact can be measured and properly articulated. It would explore new kinds of donors and partnerships with institutions and regions not considered before. It would also be assertive in its critique of donors where donor support is inappropriate for contextual conditions or challenges, or where donors are unable to foster real partnerships of mutuality with third sector organisations. 


\subsubsection{The environmental circle}

Sustainability is indeed about the environment - how to protect and sustain the structure of the household for future generations. Third sector organisations are often uniquely positioned to engage innovatively with matters of environmental sustainability at a local, national and global level.

The green economy offers opportunities that can be explored to create employment and build social capacity, to generate income, economic opportunity and financial sustainability, whilst protecting the environment. These three overlapping goals can add immense value to local processes of neighbourhood regeneration or community transformation. Burkart (2009) defines and envisions a green economy based on six main sectors, namely renewable energy, green buildings, clean transportation, water management, waste management and land management. I would like to suggest that third sector organisations, in partnership with HEls and local neighbourhoods, would do well to consider innovative engagement in one or more of these areas of green economy. It has the potential to contribute to sustainability in holistic ways.

Many social innovators working in the third sector have engaged in the green economy to further the objectives of environmental justice, economic well-being, and social and human development. Learning from such good practices and contextualising them locally could go a long way in helping to facilitate a shift from charity to agency, and a new self-consciousness among third sector organisations.

Offering local contexts as sites in which to partner with those who have already engaged in the green economy successfully in order to be mentored into this arena, as well as including HEls, would not only facilitate the generation of new and local knowledge, but would also contribute significantly to the triple bottom line of sustainability.

Textbox 5.1 proposes key elements to be included in a third sector praxis that could help facilitate sustainability in the broadest sense of the word. 'Sustaining' could be understood to refer to the actions, processes and disciplines required to sustain the third sector praxis itself, but it could also be understood to refer to the impact of the third sector praxis in terms of facilitating sustained organisations, communities, families, individuals, finances and ecologies.

An inherent mutuality is implied: we as the third sector organisation do certain things to sustain the praxis, and the praxis would then sustain the third sector organisation. The sum is more than its parts in the proposed element in the textbox - if we do the right things in the right way all the time, and I propose that the actions, processes 
and disciplines summarised here below represent some of those 'right things', the eventual impact will not be proportional to the parts, but considerably more.

TEXTBOX 5.1 Sustaining third sector praxis

\section{Sustaining third sector praxis}

- Being present in communities

- Fostering communities of shared learning

- Reading the community well, together and continuously

- Developing a reflective praxis

- Building on own assets

- Developing strong networks and partnerships

- Fostering multiple communities of care, empowerment and citizenship

- Creating and articulating alternative visions, broadly owned

- Developing clear, simple strategies with measurable outcomes and indicators

- Enabling, empowering and participating organisational structures

- Policies reflecting core values and providing a supportive, not restrictive, environment

- Broad-based resource development strategies with social enterprise at its core

- Rigorous human capacity development, affirming everyone as an agent of change

- Rituals, narratives, spaces and disciplines that sustain action, foster community, name death and celebrate signs of life

- Ability to tell stories of good news

- Capacity to participate in public processes, sharing good practices, and informing, shaping and changing policy

- Creating studios of action, reflection, dialogue and research

Third sector organisations that have reimagined themselves, conscious of their own agency, as innovative and entrepreneurial in engaging some of society's most pressing challenges, deeply reflective and self-critical of their own practices, continuously articulating what they are learning, and drawing deeply from the abundance of assets in their vicinity, are well-positioned to create and offer studios of action, reflection, dialogue and research (see Textbox 5.1), rooted in and benefiting local communities directly (De Beer 2013a; De Beer 2013b:4).

It is such a reimagined third sector that enables the reimagining of the engagement between the third sector, HEls and local neighbourhoods.

\section{REIMAGINING THE ENGAGEMENT BETWEEN THE THIRD SECTOR, HIGHER EDUCATION INSTITUTIONS AND LOCAL NEIGHBOURHOODS}

In the second part of this chapter I would like to explore a reimagined engagement between the third sector, HEls and local neighbourhoods. The emphasis "is on recognising that knowledge production is a two-way process and no longer the prerogative of universities" (Preece, Ntseane, Modise \& Osborne 2012:140). A reimagined engagement "should be seen as a mutual, reciprocal and collaborative relationship between a university and external partner" (Modise \& Mosweunyane 
2012:56). This echoes Wallis's (2006:2) view that "'community engagement" is now better defined as a two-way relationship leading to productive partnerships that yield mutually beneficial outcomes". Is it possible to reimagine the engagement between HEls, third sector organisations and local neighbourhoods as a relationship marked by mutuality and reciprocity, fostering agency, innovation and sustainability, being rooted in a paradigm of shared abundance?

\subsection{Enabling reciprocal knowledge}

An important shift in understanding the engagement between universities, third sector organisations and local neighbourhoods is a shift towards enabling reciprocal knowledge. Enabling knowledge refers to the processes of sharing, generating and transforming knowledge, while enabling knowledge (with a different emphasis) refers to the outcomes or impact of a kind of knowledge that is not simply abstract and theoretical but one that enables local change and transformation.

This type of knowledge is referred to in literature as Mode 2 knowledge, which is knowledge notjustfor its own sake, butfor the sake of social change and transformation in the communities with which it engaged: "Mode 2 knowledge, particularly in African contexts, has been highlighted as a relevant feature of engagement scholarship because it allows for practice-based knowledge that develops in context and is not confined to disciplinary boundaries" (Preece 2012:224; Gibbons 2007). It is such knowledge that relates to the purpose of this chapter: practice-based, socially transformative, contextually appropriate and inter- and transdisciplinary.

The Kellogg Commission of 1999 (Modise \& Moswuenyane 2012:57) proposed that:

$[T]$ he academy should shift from its one-way, ivory-tower, discipline-based, episodic relationships with its broader communities to engage with complex societal problems. This would increase universities' public relevance, and enhance their role as partners in building stronger regions and communities.

Enabling reciprocal knowledge refers to the locale of knowledge no longer being restricted to universities alone, but also to the nature of the relationship between the various partners. It no longer thinks only in terms of universities engaging communities on their own terms, but also in terms of third sector organisations and communities engaging universities in ways that will involve mutual benefits and impact. Schuetze (2010:25) notes that "[c]ommunity engagement is defined broadly, namely as the collaboration between institutions of higher education and their larger communities (local, regional/state, national, global) for the mutually beneficial exchange of knowledge and resources in a context of partnership and reciprocity". 
In this definition the locale of knowledge and resources is identified as both the institutions of higher education and the larger communities in which they are hosted or with which they engage. It is no longer disembodied knowledge but knowledge marked by and generated through embodied engagement (Müller 2011). It offers the possibility for communities, third sector organisations and institutions of higher education to be re-remembered to each other (De Beer 2013a), and for knowledge generation thereby to become not only locally embodied but also contextually appropriate and mutually transformative (regarding both knowledge and context).

\subsection{Exploring transdisciplinary spaces: Local neighbourhoods as sites of engagement}

Based on the above-mentioned intention of reimagined engagement between universities, third sector organisations and local neighbourhoods, exploring local neighbourhoods as sites of engagement for transdisciplinary work becomes an exciting possibility.

\subsubsection{Local neighbourhood as site of engagement}

The local neighbourhood, as a smaller unit within the city, could start to express what a learning city could look like in practice. According to Kearns, McDonald, Candy, Knight and Papadopolous (1999:6) "[a] learning city unites all the diverse providers of learning to meet the needs and aspirations of its citizens. Through the range of local resources they bring together, learning cities can provide local solutions to local challenges".

Local neighbourhoods, particularly in inner city, urban township or informal urban settlement communities (in the South African situation) present challenges ranging from water and sanitation, land and housing, economic development and social infrastructure, to public spaces, safety and security, access to basic health care, educational infrastructure, leadership and governance. This provides a rich context for action, reflection, dialogue and research.

Knowledge generation in local sites of engagement can simultaneously learn from "the needs and aspirations" (Kearns et al 1999:6) of local citizens and work in partnership with local agents of change, that is, third sector organisations and residents, "to provide solutions to local challenges".

\subsubsection{Inviting local knowledges}

One of the greatest weaknesses of university community engagement programmes is often the denial of local knowledges, thereby minimising the potential learning experience. 
Building innovative models of engagement asserting mutuality and reciprocity would require a humble entry and companionship by the university, confident participation by local organisations and residents offering their experiences and knowledges, and deliberately creating welcoming spaces for local knowledges to be heard, gathered and shared. As noted by Modise and Mosweunyane (2012:54; Yang, Zhang \& Wang 2006) "this requires a reversal of the colonising plans that are built on the assumption that local people are unenlightened. The universities, just like civil society, should counter the plan to force them to obey the moralities and values set up by their external rulers". What is required is indeed the creation of indigenous, innovative models of engagement, committed to the generation of transforming knowledge.

\subsubsection{University as equal partner}

"[U]niversities in Africa have adopted attitudes from the political north, where universities generate knowledge for communities instead of with them, thus maintaining the traditional university attitudes that offer expertise rather than appreciation of indigenous knowledge" (Modise \& Mosweunyane 2012:51). Universities have often failed to even embrace community engagement as such; the deeper conversation of how engagement should happen for it not to be generating knowledge for but with communities is often a non-existent conversation.

Community engagement is often not well embedded in universities, affected by the tension universities face between being globally competitive and financially sustainable on the one hand, and locally relevant to goals of social transformation on the other. Where community engagement or service learning projects do occur there is often little interaction between universities and their host communities or placement organisations, mitigating against optimal learning experiences for the students and reducing the potential impact for local communities (utilitarian versus based on mutuality). Institutionally, community engagement is given a subordinate role to teaching and learning, often demonstrated by low budgets, very limited infrastructure, and poor coordination of community engagement projects in many universities (Preece et al 2012:18-19). Some would also say that new languages are used for old models, but little has really changed a "vocabulary of engagement ... [that] gives credence to activities that are merely rhetoric rather than real practices for collaboration and change" (Preece et al 2012:19). But, say Franklin, Sandmann, Franklin and Settle (2008:218), "[w] hen universities engage with the complex problems in their communities, there are gains in terms of scholarship, teaching and learning. Interdisciplinary efforts gain academic vitality and public relevance that synergistically benefit each other". 
This chapter argues not only for the central position that community engagement should have in universities, particularly where they are located in postcolonial contexts of great economic and social disparity, but also that such engagement should take the form of equal partnerships with host communities and third sector organisations, instead of universities presumptuously seeking to generate knowledge for communities of which they know little.

\subsubsection{Transdisciplinary spaces}

This chapter proposes local neighbourhoods as sites of engagement, but also, more particularly, as sites for transdisciplinary engagement. Transdisciplinary spaces are spaces for interdisciplinary inquiry, generating knowledge in close collaboration with local communities: "The core idea of transdisciplinarity is different academic disciplines working jointly with practitioners to solve a real-world problem" (Klein, Grossenbacher-Mansuy, Häberli, Bill, Scholz, \& Welti 2001:4). The challenge, and beauty, of this approach is in how it enables various disciplines to work together collaboratively with local communities, reflecting on local urban challenges and experiences collectively.

De Beer (2013b:2) argues that in transdisciplinary spaces "[l]ocal urban communities would not merely be hosts for the different possible engagements, but would also serve as research partners, teachers, and collaborators in articulating local challenges, research questions and proposed solutions". In such circumstances the agency of local partners is affirmed from the onset in the very design of the engagement process. In transdisciplinary spaces knowledge is generated "not in insulated spaces but in the 'real-life' contexts of local urban communities, in close partnership with urban community practitioners, citizens and residents" (De Beer 2013b:2).

De Beer (2013b:2) refers to the quest for generating (and) transforming knowledge:

The new knowledge generated would have a possible transforming effect on students and researchers, communities of research, community practitioners and the communities or issues being researched. As such it would not only be knowledge that can transform but it would also provide spaces for existing knowledge to be transformed, deconstructing and exposing assumptions, myths, dominant constructs that are oppressive, and so forth. 


\subsubsection{Inner city of Tshwane: Imagining an embodied engagement}

In this section I would like to locate a specific embodied engagement in the inner city of Tshwane, in the form of a so-called urban studio (De Beer 2013b). ${ }^{2}$

The inner city of Tshwane (or Pretoria) has experienced dramatic transition over the past 20-25 years. It has experienced typical inner city transition, different from one neighbourhood and street to the other, and sometimes from one piece of land to the next. Disinvestment, reinvestment, racial transition, immigration, slum formation and gentrification are all forces playing themselves out on a daily basis in these neighbourhoods. The socio-economic and socio-political dynamics, cultural composition, religious diversity and environmental challenges all provide fertile soil for local engagement, practising learning and generation of knowledge.

Different third sector organisations have created significant responses to the changing dynamics, being and/or representing locally embodied citizens' organisations, residents' groups, and particularly vulnerable populations. Faith-based organisations, NPOs, local community forums and residents' associations have over the years held their ground; sometimes in an ad hoc manner, and other times in more consistent, rigorous and sophisticated ways.

It is against this background that an urban studio was proposed, as a space in which the learning, experiences and experiments of the past and the present can be used for learning and reflection. "The Urban Innovation Hub (now Urban Studio) would offer transdisciplinary spaces - ie spaces for inter-disciplinary action, reflection, learning and research - for generating knowledge in close collaboration with local communities" (De Beer 2013b:2).

The Urban Studio as proposed would be hosted by a local third sector organisation, the Tshwane Leadership Foundation, based in the inner city for more than 20 years, and working in conjunction with the Centre for Contextual Ministry at the University of Pretoria. It would also host other researchers, students, departments and centres based at the University of Pretoria and at the two other institutions of higher education in the city, as well as visiting scholars, students and researchers.

The vision of local community learning hubs, as articulated by the University of Botswana (2004:5) in their reimagining of how to engage local communities, describes what the urban innovation hub also seeks to achieve, namely "to link local

2 Initially conceptualised as an 'urban innovation hub', this innovative space between the university and the city will in future be known as an 'urban studio'. Situated in the Centre for Contextual Ministry of the Faculty of Theology at the University of Pretoria, it forms part of the broader Capital Cities Research Project of this university. 
communities and the university [or universities] and provide learning opportunities covering different areas of interest for various interest groups and to function as a community resource for innovative ideas".

The Urban Studio is an ideal space in which to foster agency, innovation and sustainability, drawing from the abundance of resources available in the creation of such a collaborative. It has the potential to contribute to knowledge generation that is socially transformative.

\subsubsection{Feast@UP: A pilot project of the Urban Studio}

An example of the kind of activities the Urban Studio is embarking on is the Feast@ UP. Feast@UP is a collaborative of students and academics at the University of Pretoria, working in partnership with the annual community festival of the Tshwane Leadership Foundation, the Feast of the Clowns. The Feast of the Clowns is a festival celebrating the city, fostering community, and creating awareness for social justice issues. Feast@UP is partnering with the Feast of the Clowns to foster a consciousness for social justice within the academic community, using the inner city as a classroom and the community festival as a space for encounter which includes action, reflection, dialogue and research.

In 2014 the activities of Feast@UP included semester courses in various departments being aligned to the festival, and students were required to reflect on their course work through the lenses of the inner city. Courses such as Community Law, Church and City, Power and Wealth, and Branding for Change, were participating in this process. The departments of visual arts and social work designed and hosted a very interactive one-day workshop for university students, community leaders, refugees and homeless people, and inner city children, entitled "Design for social justice". Students and academics also participated in workshops on homelessness, greening the city and human trafficking.

An academic colloquium entitled "The clown, the university, the city: (un)shackling liaisons" invited papers to consider the clown as metaphor for exploring the relationship between the university and the city, particularly in the contexts of freedom and shackles. A mini-march of the clowns took place on campus, seeking to create awareness for social justice issues; the Law Faculty held their annual faculty festival exploring the same theme of "(un)shackled"; and many students and academics participated in the march of the clowns through the city streets on the Saturday.

Feast@UP offers a creative space in which students, researchers, community practitioners and inhabitants of the inner city - particularly vulnerable individuals 
and groups - participate to name and analyse urban challenges, to imagine possible alternatives, and to conceptualise possible actions to embody such alternatives.

\section{FOSTERING A NEW IMAGINATION: ON SCARCITY, ABUNDANCE AND SUSTAINABILITY}

Behind the language of this chapter are basic assumptions: We live in cities and towns where vulnerability and scarcity keep the majority of residents from sharing at the table of resources. At the same time the resources of the world are abundantly adequate to overcome vulnerability and to build sustainable and resilient communities. Often the mentalities of third sector organisations, local communities and universities alike are embedded in scarcity paradigms, and therefore little sharing of resources, knowledges, experiences and people takes place.

This chapter proposes the fostering of an abundance mentality, in which sharing will be the dominant practice, and mutuality and reciprocity a given. It presupposes a reimagined third sector; shared agency in and between local communities, third sector organisations and universities; mechanisms to allow such agency to construct innovative and contextually appropriate solutions; and ensuring all of these in ways that will mediate sustainability over vulnerability for generations to come.

\section{REFERENCES}

Ashoka Innovators for the Public. [Retrieved 24 March 2014] http://www.ashoka.org

Biko S. 2002. I write what I like: Selected writings. A Stubbs (ed). 2nd Edition. Chicago: Chicago University Press.

Bornstein D. 2007. How to change the world: Social entrepreneurs and the power of new ideas. New York: Oxford University Press.

Brueggemann W 1993. Using God's resources wisely: Isaiah and urban possibility. Westminster: John Knox Press.

Brundtland Commission. 1987. Report of the World Commission on Environment and Development: Our common future. UN Documents: Gathering a Body of Global Agreements. NGO Committee on Education. [Retrieved 27 March 2014] http://www. un-documents.net/our-common-future.pdf

Burkart K. 2009. How do you define the 'green' economy? Mother Nature Network. [Retrieved 27 March 2014] http://www.mnn.com/green-tech/research-innovations/blogs/ how-do-you-define-the-green-economy

Calland R. 2013. The perfect storm that shut down Idasa. Mail \& Guardian. 28 March 2013.

Cobb JB. 1992. Sustainability: Economics, ecology and justice. New York: Orbis Books.

Collins J. 2001. Good to great: Why some companies make the leap ... and others don't. Glasgow: William Collins. 
Covey SR. 1991. Principle-centered leadership. New York: Summit Books.

De Beer S. 2013a. Absence, presence, remembrance: A theological essay on frailty, the university and the city. Verbum et Ecclesia, 34:(1):1-9.

De Beer S. 2013b. Urban Innovation Hub: Advancing community-based urban praxis through trans-disciplinary engagement. Unpublished project proposal. Pretoria: University of Pretoria.

De Gruchy S. 2003. Of agency, assets and appreciation: Seeking some commonalities between theology and development. Journal of Theology for Southern Africa, 117 (November):20-39.

Fox M. 2000. Original blessing: A primer in creation spirituality presented in four paths, twenty-six themes, and two questions. New York: Jeremy P Tarcher/Putnam.

Franklin TV, Sandmann LR, Franklin NE \& Settle TJ. 2008. Answering the question of how: Out-of-region university engagement with an economically distressed, rural region. Journal of Higher Education Outreach and Engagement, 12(3):205-220.

Gibbons M. 2007. Engagement as a Core Value in a Mode 2 Society. In: Community Engagement in Higher Education - Proceedings of the Conference. Pretoria: Council on Higher Education (CHE) Higher Education Quality Committee (HEQC) and JET Education Services (JET) Community - Higher Education - Service Partnerships (CHESP).

HM Treasury. July 2007. The future role of the third sector in social and economic regeneration: Final report. Norwich, UK: The Stationary Office. [Retrieved 24 March 2014 ] https://www.gov.uk/government/uploads/system/uploads/attachment_data/ file/228900/7189.pdf

Hopkins L. 2010. Mapping the third sector: A context for social leadership. A report prepared for Clore Social Leadership Programme. London: The Work Foundation. [Retrieved 27 March 2014] http://pdfsearch.kq5.org/ mapping-the-third sector-context-for-social-leadership/www.theworkfoundation. com*Assets*Docs*Mapping\%20the\%20Third\%20Sector.pdf/

Hull R 2007. Deprivation and Freedom: A philosophical enquiry. New York: Routledge.

Hurst A. 2012. Demystifying scaling: Part l. [Retrieved 27 March 2014] http://www.ssireview. org/blog/entry/demystifying_scaling_part_1

Inman P \& Schuetze HG. 2010. The community engagement and service mission of universities. Leicester: NIACE.

ISTR (International Society for Third-Sector Research). [Retrieved 26 March 2014] http://www. istr.org

Kearns P, McDonald R, Candy P, Knight S \& Papadopolous G. 1999. VET in the learning age: The challenge of lifelong learning for all, Volume 1. Adelaide: NCVER.

Klein JT, Grossenbacher-Mansuy W, Häberli R, Bill A, Scholz RW \& Welti M (eds). 2001. Transdisciplinarity: Joint problem solving among science, technology, and society. Birkhäuser Verlag: Basel. 332.

Lupton RD. 1993. Return flight: Community development through reneighboring our cities. Atlanta: FCS Urban Ministries. 


\section{REIMAGINING THE THIRD SECTOR, HIGHER EDUCATION INSTITUTIONS AND LOCAL NEIGHBOURHOODS}

Modise OM \& Mosweunyane D. 2012. Engagement with the city: A new paradigm for rebranding institutions of higher education. In: J. Preece, PG Ntseane, OM Modise \& M Osborne (eds). Community Engagement in African Universities: Perspectives, Prospects and Challenges. Leicester: NIACE. 49-65.

Moller Erna. (Social worker, Leprosy Mission, South Africa). Digital correspodence. 12 March 2014.

Müller JC. 2011 . Postfoundational practical theology for a time of transition. HTS Teologiese Studies/Theological Studies, 67(1): 1-5.

Preece J. 2012. Community engagement in Africa: Common themes, challenges and prospects. In: J. Preece, PG Ntseane, OM Modise \& M Osborne (eds). Community Engagement in African Universities: Perspectives, Prospects and Challenges. Leicester: NIACE. 215-229.

Preece J, Ntseane PG, Modise OM \& Osborne M. 2012. The African university and community engagement in context. In: J. Preece, PG Ntseane, OM Modise \& M Osborne (eds). Community Engagement in African Universities. Perspectives, Prospects and Challenges. Leicester: NIACE. 1-25.

RSA DoSD (Republic of South Africa. Department of Social Development). 1997. Nonprofit Organisations Act 71 of 1997. Pretoria.

Schuetze HG. 2010. The third mission of universities: Community engagement and service. In: P Inman \& HG Schuetze (eds). The Community Engagement and Service Mission of Universities. Leicester: NIACE. 13-32.

Skoll Foundation. [Retrieved 27 March 2014] http://www.skollfoundation.org

Schwab Foundation for Social Entrepreneurship. [Retrieved 24 March 2014] http://www. schwabfound.org

Stuart L. 2013. The South African nonprofit sector: Struggling to survive, needing to thrive. South African NGO Network (SANGONet). [Retrieved 31 March 2014] http://www. ngopulse.org/article/south-african-nonprofit-sector-struggling-survive-needing-thrive

Tshwane Leadership Foundation. Feast of the Clowns. [Retrieved 27 March 2014] http://www. feastoftheclowns.org.za

University of Botswana. 2004. Shaping our future: UB's strategic priorities and action to 2009 and beyond. Unpublished report. Gaborone: University of Botswana.

Walker T. 1991. Empower the people: Social ethics for the African-American church. Maryknoll, NY: Orbis.

Wallis R. 2006. What do we mean by community engagement? Paper presented at the Informa Conference Knowledge Transfer and Engagement Forum, Sydney, June 2006.

Wikipedia. 2006. Green economy. [Retrieved 24 March 2014] http://en.wikipedia.org/wiki/ Green_economy

Yang G, Zhang Q \& Wang Q. 2006. The essence, characteristics and limitation of post-colonialism: From Karl Marx's point of view. Frontiers of Philosophy in China, $1(2): 279-294$. 